Al Maal : Journal of Islamic Economics and Banking

http://jurnal.umt.ac.id/index.php/jieb

E-ISSN : $\quad 2580-3816$

Vol : 2 No. 1 Bulan Juli Tahun 2020

Hlm : $1-12$

DOI : $\quad$ : 10.31000/almaal.v2i1.2592

\title{
Analisis Strategi Pengelolaan Wakaf Uang di Indonesia (Pendekatan Metode Delphi)
}

\author{
Hendri Tanjung ${ }^{1}$, Tjetjep Suhandi², Widdy Tanzila ${ }^{3 *}$ \\ 1,2,3 Prodi Ekonomi Syariah, Fakultas Agama Islam Universitas Ibn Khaldun Bogor, Indonesia \\ *widdytanzila@gmail.com
}

\begin{abstract}
Potential cash waqf in Indonesia is enormous. However, the fact that management of waqf money is still encountering many obstacles. This study tried to identify priority constraints become a bottleneck in the management of cash waqf in Indonesia, following the priority solution that can be offered in support of the management of cash waqf in Indonesia with the approach of the Delphi method. Delphi method is a systematic method of collecting opinions from a group of expert withdrawal through a series of questionnaires based linkert scale. Based on the analysis of Delphi that rank highest priority constraint is the lack of public understanding of the waqf money followed by lack of public awareness to be charitable. The results of the analysis of Delphi that ranked highest strategic priorities with the acquisition of the average value of the same magnitude, there are three criteria, namely to provide effective education and outreach to the community about cash waqf, an innovative marketing strategy of waqf institutions, as well as the transparency and accountability of waqf institutions. It is expected that the joint commitment of various parties, academics, practitioners and policymakers in boosting cash waqf management efforts in Indonesia.
\end{abstract}

Keywords: Cash Waqf; Delphi Method; Endowments Money Management.

\section{ABSTRAK}

Potensi wakaf uang di Indonesia sangatlah besar. Akan tetapi, faktanya pengelolaan wakaf uang masih menemui kendala. Penelitian ini mencoba untuk mengidentifikasi prioritas kendala yang menjadi hambatan dalam pengelolaan wakaf uang di Indonesia, berikut prioritas solusi yang dapat ditawarkan dalam mendukung pengelolaan wakaf uang di Indonesia dengan pendekatan metode Delphi. Metode Delphi adalah metode sistematis dalam mengumpulkan penarikan opini dari sekelompok pakar melalui serangkaian kuesioner berdasarkan skala linkert. Berdasarkan hasil analisis Delphi bahwa peringkat prioritas kendala tertinggi yaitu kurangnya pemahaman masyarakat tentang wakaf uang diikuti rendahnya kesadaran masyarakat dalam berwakaf. Adapun hasil analisis Delphi bahwa peringkat prioritas strategi tertinggi dengan perolehan nilai rata-rata yang sama besarnya terdapat tiga kriteria, yaitu memberikan edukasi dan sosialisasi yang efektif kepada masyarakat mengenai wakaf uang, strategi pemasaran yang inovatif dari lembaga wakaf, serta transparansi dan akuntabilitas lembaga wakaf. Diharapkan adanya komitmen bersama dari berbagai pihak akademisi, praktisi dan pembuat kebijakan dalam mendorong upaya pengelolaan wakaf uang di Indonesia.

Kata kunci : Metode Delphi; Pengelolaan Wakaf Uang; Wakaf Uang. 


\section{Pendahuluan}

Selain industri keuangan syariah dalam keuangan Islam dikenal pula entitas keuangan sosial yang memiliki peran yang tidak kalah penting. Industri Islamic social finance tersebut antara lain adalah lembaga zakat, lembaga wakaf, baitul maal wat tamwiil dan sebagainya. Salah satu instrumen penting dan memiliki potensi yang sangat besar dari sisi sosial maupun finansial adalah wakaf uang (Rusydiana, 2018).

Wakaf uang merupakan instrumen yang memiliki potensi yang sangat besar untuk dikembangkan. Sejarah telah mencatat bahwa pemanfaatan wakaf uang di zaman Turki Usmani terbukti mampu menggerakkan perekonomian negera tersebut. Dimana saat itu Kekhilafahan Turki adalah negara terbesar yang menguasai sepertiga dunia dan pemanfaatan wakaf uang dilakukan dengan mengoptimalkan peran institusi nazir dalam menyalurkan pembiayaan berbasis wakaf uang ke sektor riil, melalui dua pola pembiayaan yang dominan, yaitu murabahah dan mudharabah (Beik, 2013).

Di Indonesia, berdasarkan data Direktorat Pemberdayaan Wakaf Kementrian Agama tertanggal Maret 2016, tercatat total tanah wakaf mencapai 435.944,317 hektare. Akan tetapi di tahun 2018, Kementrian Agraria dan Tata Ruang/Badan Pertahanan Nasional (ATR/BPN) mengungkapkan, terdapat sebanyak 460 ribu hektare tanah wakaf milik lembaga-lembaga wakaf yang tidak dimanfaatkan (idle asset). Dalam kasus ini, keberadaan model wakaf uang dipandang sebagai salah satu solusi yang dapat membuat wakaf menjadi lebih produktif. Karena uang di sini tidak lagi dipandang semata-mata sebagai alat tukar, melainkan juga komoditas yang siap dijadikan alat produksi (Nafis, 2009). Hal ini pula yang menyebabkan wakaf uang mulai dikembangkan di Indonesia pada tahun 2001, tatkala pakar ekonomi Islam melihat banyaknya asset wakaf di Indonesia tidak diberdayakan secara maksimal (Rusydiana, 2018).

Selain itu, persoalan kemiskinan merupakan salah satu problematika yang menjangkiti kehidupan di berbagai negara, termasuk di negara Indonesia. Badan Pusat Statistik (BPS) mencatat pada bulan September 2018, jumlah penduduk miskin di Indonesia mencapai 25,67 juta orang. Rendahnya taraf perekonomian merupakan masalah kompleks yang dihadapi. Keberadaan wakaf uang dipandang sebagai salah satu solusi yang sangat baik dan dapat dirasakan manfaatnya untuk meningkatkan taraf hidup masyarakat khususnya dibidang ekonomi apabila wakaf uang mampu dikelola secara professional.

Indonesia merupakan negara mayoritas berpenduduk muslim tentu akan sangat tepat jika dikaitkan dengan potensi wakaf uang di Indonesia. Menurut data Badan Wakaf Indonesia, potensi wakaf uang di Indonesia diperkirakan mencapai 180 triliun rupiah. Akan tetapi, di samping potensi yang besar terdapat kendala yang dihadapi. Faktanya potensi wakaf uang masih menemui sejumlah kendala. Hal itu dibuktikan dengan masih minimnya pengumpulan wakaf uang. Dikutip dari Republika, Ketua Divisi Humas, Sosialisasi dan Literasi, Atabik Luthfi, menyatakan dari jumlah potensi wakaf uang di Indonesia baru sebanyak 400 miliar rupiah sudah terealisasi (Aminah, 2018).

Ada beberapa faktor-faktor yang berpengaruh terhadap pengelolaan wakaf uang yang menyebabkan wakaf uang belum terealisasikan secara maksimal. Berdasarkan masalah tersebut, maka diperlukan riset terkait pengelolaan wakaf uang di Indonesia dengan pendekatan metode Delphi untuk mengidentifikasi prioritas kendala yang dihadapi dan strategi yang harus diterapkan pada sektor ini dalam kerangka strategis jangka panjang. 


\section{KAJIAN LITERATUR}

Wakaf dalam Bahasa Arab adalah isim mashdar dari kata وقف (waqafa). Menurut Al Zuhaili الوقف (al waqfu) dan التحبيس (al tahbis: menahan) serta التسبيل (al tasbil: menderma) adalah satu arti. Wakaf menurut bahasa adalah menahan dari tasharruf (Waluya, 2018).

Undang-Undang Nomor 41 Tahun 2004 menyebutkan bahwa wakaf tidak hanya benda tidak bergerak, tetapi juga dapat berupa benda bergerak, seperti uang. Lahirnya Undang-Undang No 41 Tahun 2004 dapat dikatakan sebagai momentum titik balik dalam rangka pengembangan wakaf yang lebih luas. Wakaf tidak lagi pada benda/barang yang tidak bergerak, melainkan juga untuk benda/barang bergerak. Sehingga pengembangan wakaf menjadi lebih mudah dan bernilai produktif, tidak hanya berkisar pada kuburan dan tempat peribadatan (Fuadi, 2018).

Selanjutnya Majelis Ulama Indonesia (MUI) telah mengeluarkan fatwa tentang wakaf uang sebagai berikut:

Wakaf uang (cash wakaf/waqf al-nuqud) adalah wakaf yang dilakukan seseorang, kelompok orang, lembaga, atau badan hukum dalam bentuk uang tunai.

1. Termasuk dalam pengertian ini adalah surat-surat berharga.

2. Wakaf yang hukumnya jawaz (boleh)

3. Wakaf yang hanya boleh disalurkan dan digunakan untuk hal-hal yang dibolehkan secara syar'i

4. Nilai pokok wakaf yang harus dijamin kelestariannya, tidak boleh dijual, dihibahkan dan/atau diwariskan.

Para ulama sepakat tentang diperbolehkannya wakaf uang. Diriwayatkan Imam Bukhari bahwa Imam az-Zuhri berfatwa mewakafkan dinar dan dirham hukumnya boleh. Yaitu dengan cara menjadikan dinar dan dirham tersebut sebagai modal usaha kemudian menyalurkan keuntungannya untuk kesejahteraan masyarakat. Pendapat Imam az-Zuhri diperkuat dengan pendapat Imam as-Syafi'i dan Imam Hambali yang memperbolehkan wakaf uang. Menurut Imam Hambali, dana yang didapat dari wakaf uang harus diperuntukkan dalam bentuk investasi mudharabah atau sistem bagi hasil (Direktorat Pemberdayaan Zakat dan Wakaf, 2017).

Chanifah N. (2015) menyebutkan, ada beberapa hal yang menghambat pengelolaan wakaf tunai di BMH Malang, yaitu kurangnya edukasi dan minimnya pemahaman masyarakat tentang wakaf tunai serta lemahnya sinergi antara pemerintah dan BMH Malang. Sedangkan langkah strategi mengoptimalkan pengelolaan wakaf tunai, BMH Malang melakukan beberapa hal, yakni pendekatan personal kepada masyarakat, memberikan alternatif kemudahan bagi para wakif, serta transparansi pemanfaatan dana wakaf tunai.

Haura A et al (2016) melakukan penelitian analisis pengelolaan wakaf uang di Koperasi Jasa Keuangan Syariah (KJKS). Hasil penelitian menganalisa tentang prioritas faktor-faktor strategis dalam pengelolaan wakaf uang di Koperasi Jasa Keuangan Syariah secara berurutan dari sisi internal terdapat akuntabilitas, produk, dan SDM KJKS. Sedangkan dari sisi eksternal terdapat regulasi, masyarakat umum, dan demografi. 
Hasim K et al (2016) melakukan penelitian mengenai analisis faktor yang memengaruhi penghimpunan wakaf uang. Berdasarkan hasil penelitian, faktor-faktor yang memengaruhi tingkat penghimpunan wakaf uang terbagi dalam tiga aspek, yakni kelembagaan, pemerintahan, dan masyarakat. Hasil prioritas faktor yang paling memenuhi tingkat penghimpunan wakaf uang adalah kefokusan nazhir, pemahaman masyarakat mengenai wakaf uang, dan perangkat hukum wakaf.

Rusydiana \& Rahayu (2009) melakukan penelitian strategi pengembangan wakaf tunai di Indonesia berdasarkan hasil analisis IFE. Peringkat tertinggi dari kekuatan yaitu kemampuan wakaf tunai dalam memperluas basis sumber dana wakaf. Sedangkan peringkat kelemahannya yaitu kurangnya sosialisasi kepada masyarakat. Hasil analisis EFE peringkat tertinggi dari peluang yaitu wakaf tunai yang tidak terhingga, sedangkan peringkat tertinggi dari ancaman yaitu relative lemahnya political will pemegang otoritas.

\section{Metode Penelitian}

Tahapan penelitian diawali dari studi literatur, identifikasi dan perumusan masalah, penentuan metode, penyusunan kuesioner, pengumpulan data, analisis data dan pengolahan hasil serta penyusunan kesimpulan dan saran. Responden yang terlibat pada penelitian ini merupakan pemangku kepentingan permasalahan yang diangkat serta mengetahui kondisi wakaf uang baik secara internal maupun eksternal. Responden berjumlah 7 orang yang dipilih berdasarkan kualifikasi perbedaan latar belakang yang terbagi menjadi tiga, yaitu akademisi, praktisi, dan regulator. Secara lebih rinci dapat dilihat pada tabel 1 .

Tabel 1. Klasifikasi Data Responden

\begin{tabular}{lll}
\hline No & Klasifikasi & \multicolumn{1}{c}{ Posisi } \\
\hline 1 & Regulator & Wakil Bendahara Badan Wakaf Indonesia \\
2 & Regulator & Divisi Humas, Sosialisasi, dan Literasi Wakaf Badan Wakaf Indonesia \\
3 & Regulator & Divisi Pendataan dan Sertifikasi Wakaf Badan Wakaf Indonesia \\
4 & Praktisi & General Manager Mobilisasi Wakaf Dompet Dhuafa \\
5 & Praktisi & Manager Pengembangan Harta Wakaf Baitulmaal Muamalat \\
6 & Akademisi & Ketua Program Studi Magister Manajemen, Sekolah Pascasarjana \\
7 & Akademisi & Dosen STEI SEBI \\
\hline
\end{tabular}

Metode Delphi adalah proses kelompok yang melibatkan interaksi antara peneliti dan sekelompok ahi terkait dengan topik tertentu melalui bantuan kuesioner. Metode ini berguna pada saat pendapat dan penilaian dari para ahli dan praktisi dibutuhkan dalam menyelesaikan masalah. Ini akan sangat berguna ketika para ahli tidak bisa dihadirkan pada saat yang sama (Rum \& Heliati, 2018). Mayoritas penelitian metode Delphi menggunakan kuesioner dengan skala linkert, rangking preferensi atau kombinasi (Loe, Melnychuk \& Plummer, 2016). Penelitian ini menggunakan penarikan opini dengan skala linkert 1 sampai 9, dimana 1 berarti sangat tidak penting dan 9 berarti sangat penting. Model ini

Terdapat tiga indikator statistik yang paling banyak digunakan dalam aplikasi metode Delphi, yaitu nilai mean (rata-rata), standar deviasi, dan interquartile range. indikator statistik ini digunakan untuk melihat tingkat konvergensi dari para responden. 
Konvergensi opini merupakan hasil akhir dari metode Delphi (Sossa, Halal \& Zarta, 2019). Ukuran pertama penilaian konvergensi atau konsensus adalah ketika jawaban atau penilaian dari seluruh responden memiliki nilai standar deviasi $<1,5$. Adapun rumus sebagai berikut

$$
\sqrt{\frac{\sum\left(x_{i}-\bar{x}\right)^{2}}{n-1}}
$$

$\mathrm{x}=$ jawaban responden $\mathrm{A}$ terhadap instrument $\mathrm{n}$

$\bar{x}=$ rata-rata jawaban responden terhadap instrument $\mathrm{n}$

Ukuran kedua yaitu penilaian konvergensi atau konsensus. Digunakan ketika jawaban atau penilaian dari seluruh responden memiliki nilai Jangkauan Interkuartile (Interquartile Range/IR) $<2,5$. Adapun penghitungan Interquartile Range adalah (IR = $Q_{3}-Q_{1}$ ) dimana $Q_{3}$ adalah kuartil atas dan $Q_{1}$ adalah kuartil bawah. Adapun rumus kuartil atas sebagai berikut:

$$
\begin{gathered}
Q_{1}=\frac{x_{\left(\frac{n-1}{4}\right)}+x_{\left(\frac{n+3}{4}\right)}}{2} \\
Q_{2}=x\left(\frac{2(n+1)}{4}\right) \\
Q_{3}=\frac{x_{\left(\frac{3 n+1}{4}\right)}+x_{\left(\frac{3 n+5}{4}\right)}}{2}
\end{gathered}
$$

Untuk menyatakan konvergensi atau konsensus terhadap seluruh kriteria adalah ketika nilai standar deviasi $<1,5$ dan nilai Interquartile Range $<2,5$. Jika salah satu indikator tidak mencapai syarat, maka kriteria tersebut dinyatakan tidak konvergen atau tidak disepakati. Sedangkan untuk kriteria yang mencapai syarat, langkah selanjutnya ialah melakukan pemeringkatan dengan nilai rata-rata tertinggi untuk setiap kriteria yang mencapai kovergen atau konsensus

\section{HASIL DAN PEMBahasan Hasil Metode Delphi}

\section{Kuesioner Tahap I}

Untuk menyusun kuesioner, peneliti mengidentifikasi kriteria-kriteria penentu untuk penarikan opini kendala dan strategi pengelolaan wakaf uang di Indonesia berdasarkan literatur dan studi terkait serta mendiskusikan dengan para pakar untuk memvaliditasi. Adapun hasil kuesioner tahap I sebagai berikut:

Tabel 2. Kriteria Kendala Pengelolaan Wakaf Uang di Indonesia

\begin{tabular}{ll}
\hline No & \multicolumn{1}{c}{ Kendala/Keterbatasan } \\
\hline 1 & Kurangnya koordinasi antara nazhir, LKS-PWU, dan pemerintah \\
2 & Kurangnya kepercayaan masyarakat terhadap lembaga wakaf \\
3 & Kurangnya transparansi pengelolaan wakaf uang \\
4 & Lemahnya political will pemegang otoritas \\
5 & Kurangnya profesionalisme nazhir
\end{tabular}


$6 \quad$ Kurangnya pemahaman masyarakat tentang wakaf uang

$7 \quad$ Rendahnya kesadaran masyarakat dalam berwakaf

8 Belum optimalnya jejaring pemberdayaan dan pengembangan wakaf uang

9 Lemahnya Undang-Undang perwakafan

Tabel 4. Kriteria Strategi Pengelolaan Wakaf Uang di Indonesia

\begin{tabular}{ll}
\hline No & \multicolumn{1}{c}{ Strategi/Solusi } \\
\hline 1 & Memberikan edukasi dan sosialisasi yang efektif kepada masyarakat mengenai wakaf \\
2 & Mang \\
3 & Mengutamakan kesejahteraan aspek materiil nazhir \\
4 & Transparansi dan akuntabilitas lembaga wakaf \\
5 & Komputerisasi manajemen pengelolaan dana wakaf uang \\
6 & Strategi pemasaran yang inovatif dari lembaga wakaf \\
7 & Membina hubungan baik antara nadhir, LKS-PWU dan pemerintah \\
8 & Support regulasi/ Undang-Undang Wakaf \\
\hline
\end{tabular}

\section{Kuesioner Tahap II}

Kuesioner tahap II merupakan lanjutan dari kuesioner tahap I dengan penarikan opini dari responden bidang akademisi dan praktisi.

Tabel 5. Penarikan Opini Kuesioner Kendala Tahap II

\begin{tabular}{lcccc}
\hline \multicolumn{1}{c}{ Responden } & \multirow{2}{*}{ R1 } & $\boldsymbol{R} 2$ & $\boldsymbol{R 3}$ & $\boldsymbol{R 4}$ \\
\hline$X_{1}$ & & & & \\
$X_{2}$ & 7 & 8 & 9 & 9 \\
$X_{3}$ & 9 & 5 & 5 & 9 \\
$X_{4}$ & 6 & 8 & 9 & 6 \\
$X_{5}$ & 5 & 4 & 8 & 8 \\
$X_{6}$ & 9 & 9 & 5 & 5 \\
$X_{7}$ & 9 & 9 & 9 & 9 \\
$X_{8}$ & 8 & 9 & 9 & 9 \\
$X_{9}$ & 5 & 5 & 7 & 5 \\
\hline
\end{tabular}

Tabel 6. Penarikan Opini Kuesioner Strategi Tahap II

\begin{tabular}{lllll}
\hline \multicolumn{1}{c}{ Strategi } & Responden & $\boldsymbol{R} 2$ & $\boldsymbol{R 3}$ & $\boldsymbol{R 4}$ \\
\cline { 1 - 4 }$X_{1}$ & & & & \\
$X_{2}$ & 9 & 9 & 9 & 9 \\
$X_{3}$ & 4 & 6 & 5 & 5 \\
$X_{4}$ & 5 & 9 & 9 & 9 \\
$X_{5}$ & 7 & 9 & 9 & 9 \\
$X_{6}$ & 8 & 8 & 7 & 8 \\
$X_{7}$ & 9 & 9 & 8 & 9 \\
$X_{8}$ & 9 & 8 & 8 & 8 \\
\hline
\end{tabular}


Penilaian di atas merupakan peringkat dari prioritas terbesar sampai yang terkecil dari setiap kriteria penentu dalam pemilihan objek dari responden bidang akademisi dan praktisi. Berikut perhitungan statistik dari tabulasi di atas.

Tabel 7. Hasil Perhitungan Kuesioner Kendala Tahap II

\begin{tabular}{lllllllll}
\hline \multirow{2}{*}{ No } & Mean & Std. Dev & $\boldsymbol{Q 1}$ & $\mathbf{Q 2}$ & $\mathbf{Q 3}$ & $\boldsymbol{I R}$ & $\begin{array}{c}\text { Evaluasi } \\
\text { Std. Dev }\end{array}$ & \multicolumn{1}{c}{$\boldsymbol{I R}$} \\
\hline 1 & 8,25 & 0,829 & 7,75 & 8,5 & 9 & 1,25 & Konvergen & Konvergen \\
2 & 7 & 2 & 5 & 7 & 9 & 4 & Divergen & Divergen \\
3 & 7,25 & 1,299 & 6 & 7 & 8,25 & 2,25 & Konvergen & Konvergen \\
4 & 6,25 & 1,785 & 4,75 & 6,5 & 8 & 3,25 & Divergen & Divergen \\
5 & 7 & 2 & 5 & 7 & 9 & 4 & Divergen & Divergen \\
6 & 9 & 0 & 9 & 9 & 9 & 0 & Konvergen & Konvergen \\
7 & 8,75 & 0,433 & 8,75 & 9 & 9 & 0,25 & Konvergen & Konvergen \\
8 & 5,5 & 0,866 & 5 & 5 & 5,5 & 0,5 & Konvergen & Konvergen \\
9 & 5 & 1,224 & 4 & 4,5 & 5,5 & 1,5 & Konvergen & Konvergen \\
\hline \multicolumn{6}{c}{ Keterangan: Std. Dev(Standar Deviasi); IR(Interquartile Range) }
\end{tabular}

Sumber data diolah oleh penulis

Berdasarkan perhitungan yang dilakukan diketahui bahwa kriteria yang konvergen dan tercapai konsensus berjumlah 6 kriteria. Sementara 3 kriteria lainnya tidak tercapai konvergensi atau konsensus. Dapat dilihat pada nomor 2, 4, dan 5 nilai standar deviasi dan interquartile range cenderung besar. Hal ini menunjukkan penarikan opini dari masing-masing responden belum sepakat bahwa kriteria kurangnya kepercayaan masyarakat terhadap lembaga wakaf, lemahnya political will pemegang otoritas, dan kurangnya profesionalisme nazhir adalah prioritas penentu kendala pengelolaan wakaf uang di Indonesia.

Tabel 8. Hasil Perhitungan Kuesioner Strategi Tahap II

\begin{tabular}{lllllllll}
\hline \multirow{2}{*}{ No } & Mean & Std. Dev & $\boldsymbol{Q 1}$ & $\mathbf{Q 2}$ & $\mathbf{Q 3}$ & $\mathbf{I R}$ & \multicolumn{2}{c}{$\begin{array}{c}\text { Evaluasi } \\
\text { Std. Dev }\end{array}$} \\
\hline 1 & 9 & 0 & 9 & 9 & 9 & 0 & Konvergen & Konvergen \\
2 & 5 & 0,707 & 4,75 & 5 & 5,25 & 0,5 & Konvergen & Konvergen \\
3 & 8 & 1,732 & 8 & 9 & 9 & 1 & Divergen & Konvergen \\
4 & 8,5 & 0,866 & 8,5 & 9 & 9 & 0,5 & Konvergen & Konvergen \\
5 & 7,75 & 0,433 & 7,75 & 8 & 8 & 0,25 & Konvergen & Konvergen \\
6 & 8,75 & 0,433 & 8,75 & 9 & 9 & 0,25 & Konvergen & Konvergen \\
7 & 8,25 & 0,433 & 8 & 8 & 8,25 & 0,25 & Konvergen & Konvergen \\
8 & 7,25 & 1,089 & 6,75 & 7 & 7,5 & 0,75 & Konvergen & Konvergen \\
\hline \multicolumn{8}{c}{ Sumber data diolah oleh penulis }
\end{tabular}

Dari perhitungan di atas menunjukkan penarikan opini dari masing-masing responden cenderung kecil, dimana nilai standar deviasi $<1,5$ dan nilai interquartile range $<2,5$. Sementara kriteria yang tidak mencapai konvergensi atau konsensus ialah nomor 3, yaitu meningkatkan intensitas dan efektifitas training nazhir secara berkesinambungan. Hal ini berarti responden belum sepakat bahwa kriteria tersebut adalah penentu strategi pengelolaan wakaf uang di Indonesia. 


\section{Kuesioner Tahap III}

Karena pada penarikan opini putaran pertama belum menghasilkan prioritas kriteria yang potensial, maka dilakukan penarikan opini putaran kedua. Pada tahapan ini penarikan opini dilakukan oleh responden bidang regulator. Pada putaran kedua ini, responden merupakan expert (pakar) dan juga pemangku kepentingan terkait pengelolaan wakaf uang di Indonesia. Berdasarkan jawaban penarikan opini, terlihat hasil jawaban para responden bidang regulator sebagai berikut:

Tabel 9. Penarikan Opini Kuesioner Kendala Tahap III

\begin{tabular}{|c|c|c|c|}
\hline Kendala & $R 1$ & $R 2$ & $R 3$ \\
\hline$X_{l}$ & 9 & 7 & 7 \\
\hline$X_{2}$ & 9 & 9 & 6 \\
\hline$X_{3}$ & 7 & 9 & 7 \\
\hline$X_{4}$ & 4 & 4 & 5 \\
\hline$X_{5}$ & 6 & 9 & 8 \\
\hline$X_{6}$ & 9 & 8 & 9 \\
\hline$X_{7}$ & 9 & 7 & 9 \\
\hline$X_{8}$ & 7 & 8 & 9 \\
\hline$X_{9}$ & 5 & 5 & 8 \\
\hline
\end{tabular}

Tabel 10. Penarikan Opini Kuesioner Strategi Tahap III

\begin{tabular}{|c|c|c|c|}
\hline $\begin{array}{l}\text { Responden } \\
\text { Strategi }\end{array}$ & $R 1$ & $R 2$ & $R 3$ \\
\hline$X_{1}$ & 9 & 9 & 9 \\
\hline$X_{2}$ & 6 & 8 & 5 \\
\hline$X_{3}$ & 9 & 9 & 7 \\
\hline$X_{4}$ & 9 & 9 & 9 \\
\hline$X_{5}$ & 6 & 7 & 8 \\
\hline$X_{6}$ & 9 & 9 & 9 \\
\hline$X_{7}$ & 8 & 6 & 7 \\
\hline$X_{8}$ & 8 & 7 & 8 \\
\hline
\end{tabular}

Berikut hasil perhitungan kuesioner kendala dan strategi tahap III.

Tabel 11. Hasil Perhitungan Kuesioner Kendala Tahap III

\begin{tabular}{lllllllll}
\hline \multirow{2}{*}{ No } & \multirow{2}{*}{ Mean } & Std. Dev & $\boldsymbol{Q 1}$ & $\boldsymbol{Q 2}$ & $\mathbf{Q 3}$ & $\mathbf{I R}$ & \multicolumn{2}{c}{ Evaluasi } \\
& & & & & & & \multicolumn{1}{c}{ Std. Dev } & \multicolumn{1}{c}{$\boldsymbol{I R}$} \\
\hline 1 & 7,6 & 0,942 & 7 & 7 & 8 & 1 & Konvergen & Konvergen \\
2 & 8 & 1,414 & 7,5 & 9 & 9 & 1,5 & Konvergen & Konvergen \\
3 & 7,6 & 0,942 & 7 & 7 & 8 & 1 & Konvergen & Konvergen \\
4 & 4,3 & 0,471 & 4 & 4 & 4,5 & 0,5 & Konvergen & Konvergen \\
5 & 7,6 & 1,247 & 7 & 8 & 8,5 & 1,5 & Konvergen & Konvergen \\
6 & 8,6 & 0,471 & 8,5 & 9 & 9 & 0,5 & Konvergen & Konvergen \\
7 & 8,3 & 0,942 & 8 & 9 & 9 & 1 & Konvergen & Konvergen \\
8 & 8 & 0,816 & 7,5 & 8 & 8,5 & 1 & Konvergen & Konvergen \\
9 & 6 & 1,414 & 5 & 5 & 8,5 & 1,5 & Konvergen & Konvergen \\
\hline
\end{tabular}


Dari perhitungan statistik kuesioner kendala tahap III didapatkan rentang nilai standar deviasi yang sudah mengecil. Pada kuesioner kendala tahap II yang tercapai konvergensi atau konsensus hanya 6 kriteria, sedangkan pada kuesioner kendala tahap III terlihat hasil yang lebih baik dimana seluruh nilai standar deviasi $<1,5$ dan nilai interquartile range $<2,5$. Hal ini berarti seluruh kriteria tercapai kovergensi atau konsensus. Para responden sepakat bahwa kriteria tersebut penentu kendala pengelolaan wakaf uang di Indonesia.

Tabel 12. Hasil Perhitungan Kuesioner Strategi Tahap III

\begin{tabular}{lllllllll}
\hline \multirow{2}{*}{ No } & \multirow{2}{*}{ Mean } & Std. Dev & $\boldsymbol{Q 1}$ & $\boldsymbol{Q} 2$ & $\mathbf{Q 3}$ & $\boldsymbol{I R}$ & \multicolumn{3}{c}{ Evaluasi } \\
& & & & & & & Std. Dev & \multicolumn{1}{c}{$\boldsymbol{I R}$} \\
\hline 1 & 9 & 0 & 9 & 9 & 9 & 0 & Konvergen & Konvergen \\
2 & 6,3 & 1,247 & 5,5 & 6 & 7 & 1,5 & Konvergen & Konvergen \\
3 & 8,3 & 0,942 & 8 & 9 & 9 & 1 & Konvergen & Konvergen \\
4 & 9 & 0 & 9 & 9 & 9 & 0 & Konvergen & Konvergen \\
5 & 7 & 0,816 & 6,5 & 7 & 7,5 & 1 & Konvergen & Konvergen \\
6 & 9 & 0 & 9 & 9 & 9 & 0 & Konvergen & Konvergen \\
7 & 7 & 0,816 & 6,5 & 7 & 7,5 & 1 & Konvergen & Konvergen \\
8 & 7,6 & 0,471 & 7,5 & 8 & 8 & 0,5 & Konvergen & Konvergen \\
\hline \multicolumn{6}{c}{ Sumber data diolah oleh penulis }
\end{tabular}

Dari perhitungan statistik kuesioner strategi tahap III seluruh kriteria tercapai konvergensi atau konsensus dimana seluruh nilai standar deviasi <1,5 dan nilai interquartile range $<2,5$. Penarikan opini dihentikan pada tahap ini karena nilai standar deviasi dan interquartile pada kuesioner kendala dan strategi sudah menurun yang menunjukkan bahwa responden terhadap setiap kriteria dapat dikatakan mencapai konsensus.

\section{Analisis Metode Delphi}

Berdasarkan nilai mean (rata-rata), telah terdapat pilihan prioritas kriteria kendala yang potensial untuk dibenahi guna meningkatkan pengelolaan wakaf uang di Indonesia serta prioritas strategi yang potensial untuk dikembangkan dalam mengelola wakaf uang di Indonesia.

Tabel 13. Peringkat Kriteria Kendala

\begin{tabular}{lll}
\hline \multicolumn{1}{c}{ Kriteria Kendala Pengelolaan Wakaf Uang } & Mean & Rank \\
\hline Kurangnya pemahaman masyarakat tentang wakaf uang & 8,6 & 1 \\
Rendahnya kesadaran masyarakat dalam berwakaf & 8,3 & 2 \\
Belum optimalnya jejaring pemberdayaan dan pengembangan wakaf uang & 8 & 3 \\
Kurangnya kepercayaan masyarakat terhadap lembaga wakaf & 8 & 4 \\
Kurangnya koordinasi antara nazhir, LKS-PWU, dan pemerintah & 7,6 & 5 \\
Kurangnya transparansi pengelolaan wakaf uang & 7,6 & 6 \\
Kurangnya profesionalisme nazhir & 7,6 & 7 \\
Lemahnya Undang-Undang perwakafan & 6 & 8 \\
Lemahnya Political will pemegang otoritas & 4,3 & 9 \\
\hline
\end{tabular}

Sumber data diolah oleh penulis 
Hasil analisis metode Delphi menunjukkan bahwa kurangnya pemahaman masyarakat tentang wakaf uang mempunyai peringkat rata-rata tertinggi yaitu sebesar 8,6 yang artinya kriteria ini mempunyai pengaruh yang paling besar dalam melemahkan pengelolaan wakaf uang. Literasi masyarakat terkait wakaf uang adalah kunci untuk tantangan pengelolaan wakaf uang di Indonesia. Hal ini relevan dengan hasil penelitian yang dilakukan oleh Chanifah (2015) mengemukakan bahwa salah satu faktor yang menghambat pengelolaan wakaf uang di Baitul Maal Hidayatullah yaitu minimnya pemahaman masyarakat terkait wakaf uang.

Sedangkan peringkat kedua ialah masih rendahnya kesadaran masyarakat dalam berwakaf dengan nilai rata-rata sebesar 8,3 yang artinya mempunyai pengaruh cukup besar. Inisiatif pemilik harta merupakan elemen prioritas karena merupakan kesadaran sendiri dari dalam pribadi seseorang untuk berwakaf. Dengan adanya kesadaran sendiri tentu akan lebih mudah untuk menyalurkan wakaf uang

Tabel 14. Peringkat Kriteria Strategi

\begin{tabular}{lll}
\hline \multicolumn{1}{c}{ Kriteria Strategi Pengelolaan Wakaf Uang } & Mean & Rank \\
\hline $\begin{array}{l}\text { Memberikan edukasi dan sosialisasi yang efektif kepada masyarakat } \\
\text { mengenai wakaf uang }\end{array}$ & 9 & 1 \\
Strategi pemasaran yang inovatif dari lembaga wakaf & 9 & 2 \\
Transparansi dan akuntabilitas lembaga wakaf & 9 & 3 \\
Meningkatkan intensitas dan efektifitas training nazhir secara & 8,3 & 4 \\
berkesinambungan & 7,6 & 5 \\
Support regulasi/Undang-Undang Wakaf & 7 & 6 \\
Membina hubungan baik antara nazhir, LKS-PWU, dan pemerintah & 7 & 7 \\
Komputerisasi manajemen pengelolaan dana wakaf uang & 6,3 & 8 \\
Mengutamakan kesejahteraan aspek materiil nazhir & & \\
\hline
\end{tabular}

Sumber data diolah oleh penulis

Hasil analisis metode Delphi menunjukkan bahwa dari sisi strategi, kriteria memberikan edukasi dan sosialisasi yang efektif kepada masyarakat mengenai wakaf uang, strategi pemasaran yang inovatif dari lembaga wakaf, serta transparansi dan akuntabilitas lembaga wakaf mempunyai peringkat rata-rata tertinggi yaitu sebesar 9 yang artinya mempunyai pengaruh yang paling besar sebagai peluang dalam meningkatkan wakaf uang. Sedangkan peringkat terendah dengan nilai rata-rata sebesar 6,3 ialah mengutamakan kesejahteraan aspek materiil nazhir yang maknanya kriteria ini diberi nilai paling rendah oleh para responden dari perspektif strategi.

Relevan dengan hasil penelitian Hasim K et al (2016), Haura A et al (2016), dan Rusydiana \& Rahayu (2018). Prioritas utama strategi pada aspek masyarakat adalah pemahaman masyarakat mengenai wakaf uang. Semakin tinggi tingkat pemahaman masyarakat mengenai wakaf uang akan memberikan peluang lebih besar untuk memberikan kontribusi dalam penghimpunan wakaf uang (Hasim K et al, 2016). Wakaf uang harus disosialisasikan secara lebih masif dan terstruktur agar lebih memberikan pemahaman yang komprehensif terhadap seluruh kalangan dan public secara umum dalam rangka kemaslahatan yang lebih besar dan luas (Rusydiana \& Rahayu, 2019). Menurut Haura A et al (2016), transparansi dinilai penting karena merupakan poin yang dapat memberikan gambaran kondisi sebuah lembaga. Selain itu juga dianggap berbanding lurus dengan kepercayaan masyarakat jika lembaga memiliki asset besar tentu mendapat kepercayaan lebih karena mampu mengelola dana dalam jumlah besar. 
Penelitian ini membuktikan hal penting lainnya yang mempengaruhi pengelolaan wakaf uang adalah faktor transparansi keuangan (akuntabilitas). Hal ini menyiratkan bahwa lembaga wakaf harus bertanggung jawab penuh dalam mengelola dana wakaf dalam menjaga trust masyarakat. Akan tetapi, sejauh ini Baitulmaal Muamalat menjadi satu-satunya lembaga wakaf yang telah memisahkan antara laporan keuangan zakat dan laporan keuangan wakaf berdasarkan PSAK 112. Ini perlu menjadi perhatian bagi lembaga wakaf lainnya untuk segera menindaklanjuti transparansi keuangan yang tidak kalah penting disamping memberikan edukasi kepada masyarakat dan pemasaran yang kreatif dan inovatif.

\section{KESIMPULAN}

Dalam rangka terwujudnya potensi wakaf uang di Indonesia, maka yang harus diketahui terlebih dahulu dua faktor penting, yaitu kendala serta strategi pengelolaan wakaf uang. Berdasarkan hasil analisis metode Delphi, dapat diambil kesimpulan bahwa prioritas faktor kendala yang dihadapi dalam pengelolaan wakaf uang di Indonesia, yaitu kurangnya pemahaman masyarakat tentang wakaf uang. Adapun prioritas strategis yang paling mempengaruhi tingkat pengelolaan wakaf uang di Indonesia secara berurutan adalah memberikan edukasi dan sosialisasi yang efektif kepada masyarakat mengenai wakaf uang, strategi pemasaran yang inovatif dari lembaga wakaf, serta transparansi dan akuntabilitas lembaga wakaf.

Penelitian ini merupakan penelitian yang menganalisis pengelolaan wakaf uang di Indonesia yang didasarkan hanya pada aspek prioritas kendala dan strategi saja. Melalui penelitian ini diharapkan dapat memberikan kajian terkait wakaf uang di Indonesia serta dapat memberikan kontribusi positif bagi akademisi, praktisi dan regulator dalam mendorong upaya pengembangan wakaf uang di Indonesia.

\section{REFERENSI}

Rusydiana, A. S. 2018, Analysis of Cash Waqf Development In Indonesia Using Interpretive Structural Modeling (ISM). Journal of Islamic Economics Lariba, $4(1), 1-11$

Beik, I. S. 2013, Mengoptimalkan Wakaf Uang Bagi Pengembangan UMKM. Iqtishodia Jurnal Ekonomi Islam Republika. 23

Nafis, Cholil. 2008. Menggali Sumber Dana Umat Melalui Wakaf Uang. 12 Januari 2020. https://www.bwi.go.id/91/2008/02/artikel/menggali-sumber-dana-umat-melaluiwakaf-uang-2/

Aminah, Nur. 2018. Potensi Wakaf Tunai Capai Rp 180 Triliun. 21 Januari 2020. https://www.republika.co.id/berita/dunia-islam/wakaf/18/10/16/pgovmd384potensi-wakaf-tunai-capai-rp-180-triliun

Badan Pusat Statitik. 2019. Persentase Penduduk Miskin Pada September 2018 Sebesar 9,66 Persen. $30 \quad 2019$. https://www.bps.go.id/pressrelease/2019/01/15/1549/persentase-pendudukmiskin-pada-september-2018-sebesar-9-66-persen.html 
Hendri Tanjung, Tjetjep Suhandi, \& Widdy Tanzila

Waluya, Atep Hendang. 2018. Istibdal Wakaf Dalam Pandangan Fukaha Klasik Dan Kontemporer. Misykat al-Anwar Jurnal Kajian Islam dan Masyarakat. Vol 29, No 2 (2018). 51

Fuadi, N. F. Z. (2018). Wakaf Sebagai Instrumen Ekonomi Pembangunan Islam. Economica: Jurnal Ekonomi Islam, 9(1), 151-177.

Kementerian Agama Republik Indonesia. (2017). Himpunan Peraturan PerundangUndangan Tentang Wakaf. Jakarra: Direktorat Jendral Bimbingan Masyarakat Islam Direktorat Pemberdayaan Zakat dan Wakaf.

Haura, A., Baga, L. M., \& Tanjung, H. (2015). Analisis Pengelolaan Wakaf Uang Pada Koperasi Jasa Keuangan Syariah (Pendekatan Analytical Network Process). AlMuzara'ah, 3(2), 89-105.

Chanifah, N. 2015. Strategi Pengelolaan Wakaf Tunai Dalam Upaya Mewujudkan Kesejahteraan Umat (Studi Kasus Di Baitul Maal Hidayatullah Malang). Prosiding SNaPP: Sosial, Ekonomi dan Humaniora, 5(1), 29-36.

Rusydiana, A., \& Rahayu, S. S. 2019. Bagaimana Strategi Pengembangan Wakaf Tunai Di Indonesia?. Jurnal Ekonomi dan Bisnis Islam (JEBIS), 5(1), 15-33.

Hasim, K., Lubis, D., \& Ali, K. M. 2016. Analisis Faktor-Faktor yang Memengaruhi Penghimpunan Wakaf Uang di Indonesia (Pendekatan Analytical Network Process). Al-Muzara'ah, 4(2), 127-141.

De Loë, R. C., Melnychuk, N., Murray, D., \& Plummer, R. 2016, Advancing The State Of Policy Delphi Practice: A Systematic Review Evaluating Methodological Evolution, Innovation, And Opportunities.

Rum, \& Heliati. (2018). Modul Metode Delphi. Untuk Direktorat Jasa Keuangan dan BUMN BAPPENAS

Sossa, J. W. Z., Halal, W., \& Zarta, R. H. 2019. Delphi Method: Analysis Of Rounds, Stakeholder And Statistical Indicators. foresight.

Baitulmaal Muamalat. 2019. BMM Serahkan Laporan Wakaf Kepada Badan Wakaf Indonesia. 20 Februari 2020. http://bmm.or.id/news/read/140/bmm-serahkanlaporan-wakaf-kepada-badan-wakaf-indonesia 